\title{
GAMBARAN PENGARUH IMPLEMENTASI KNOWLEDGE MANAGEMENT TERHADAP KINERJA PEGAWAI PADA BADAN PENGELOLAAN PENDAPATAN DAERAH KOTA BANDUNG
}

\author{
Shenny Syafarina \\ Universitas Pendidikan Indonesia \\ shenny.syafarina@student.upi.edu \\ Syamsul Hadi Senen \\ Universitas Pendidikan Indonesia \\ syamsulhadisenen@upi.edu \\ Sumiyati \\ Universitas Pendidikan Indonesia \\ sumiyati@upi.edu
}

\begin{abstract}
ABSTRAK
Tujuan - Tujuan penelitian ini adalah untuk mengetahui gambaran pengaruh implementasi knowledge management terhadap kinerja pegawai Badan Pengelolaan Pendapatan Daerah Kota Bandung.

Desain / metodologi / pendekatan - Desain penelitian adalah cross-sectional. Penelitian ini menggunakan pendekatan deskriptif dengan metode explanatory survey. Unit analisis pegawai sebanyak 74 orang. Pengumpulan data dengan menggunakan kuesioner. Teknik analisis yang digunakan adalah teknik deskriptif dengan menggunakan distribusi frekuensi.

Temuan - Berdasarkan hasil penelitian, didapatkan hasil bahwa knowledge management berada pada kategori baik dengan perolehan skor $81,9 \%$, dan kinerja pegawai berada pada kategori tinggi dengan perolehan skor $86 \%$.

Orisinalitas / nilai - Penelitian ini memberikan dasar untuk memahami gambaran implementasi knowledge management, dan kinerja pegawai. Perbedaan penelitian ini dengan penelitian sebelumnya adalah pada objek, variabel, teori, serta referensi yang digunakan oleh peneliti dengan peneliti sebelumnya.

$\begin{array}{ll}\text { Kata Kunci } & : \text { Knowledge Management, Kinerja Pegawai } \\ \text { Jenis Artikel } & : \text { Studi Kasus }\end{array}$

Purpose - The purpose of this research is to know the decription the influence of knowledge management implementation toward employee performance in Bandung city revenue Management agency.

Design/methodology/approach - The Research design is cross sectional. This research is using descriptive approach with explanatory survey method. The analysis unit is 74 employees. Collecting the data is using questionnaire. Analysis technique used is descriptive technique with using frequency distribution.

Finding - Based on the result of research, the results obtained that knowledge managemnt in the category is good with a score $81,9 \%$, and employee performence is in high category with a score $86 \%$. Originality/value - This research giving a basic for understanding work dicipline, work culture and issues on organizatonal citizenship behavior. The difference of this research with the previous research are on the object, variable, theory and references.
\end{abstract}

Keywords: Knowledge Management, Employee Performence

Article Type : Case Study 


\section{PENDAHULUAN}

Keberadaan manusia sebagai sumber daya Persoalan Manajemen Sumber Daya Manusia (MSDM) merupakan salah satu faktor penting dalam suatu organisasi. Manajemen sumber daya manusia tersebut harus dikelola secara efektif dan efisien untuk mendukung dalam mencapai visi, misi dan tujuan organisasi tersebut. MSDM adalah aset paling berharga bagi setiap organisasi karena mereka dapat membangun atau menghancurkan reputasi organisasi dan mereka dapat mempengaruhi profitabilitas (Elnaga \& Imran, 2013). MSDM merupakan komponen penting organisasi yang tidak bisa digantikan oleh sumber daya lain. Keberhasilan dan kemunduran organisasi ditentukan oleh kualitas dan kapabilitas SDM didalamnya (Khan, Abbasi, Waseem, Ayaz, \& Ijaz, 2016). MSDM juga dinilai lebih penting daripada komponen lainnya untuk mencapai hasil kinerja yang diinginkan (Cania, 2014).

Rendahnya kinerja pegawai masih menjadi masalah utama yang berkaitan dengan sumber daya manusia karena seluruh keberhasilan organisasi atau lembaga dalam mencapai tujuan strategisnya sangat bergantung pada tingkat kinerja pegawai. Kinerja perusahaan merupakan hasil kerja atas suatu pekerjaan yang telah dihasilkan dari perilaku nyata karyawan secara kualitas dan kuantitas sesuai dengan tugas yang diberikan kepadanya (Senen, 2016).

Penataan dan peningkatan kinerja pegawai dalam pemerintahan harus memperoleh perhatian guna menyikapi sebuah modernisasi untuk perwujudan tata pemerintahan yang baik (good govermance) (Charis Christiani, 2013). Pegawai Negeri Sipil (PNS) sebagai alat pemerintah (aparatur pemerintah) memiliki keberadaan yang sentral dalam membawa komponen kebijakan atau peraturanperaturan pemerintah. Komponen tersebut terakumulasi dalam bentuk pendistribusian tugas, fungsi dan kewajiban PNS (Astiasa, 2015). Pandangan masyarakat saat ini mengenai kinerja Aparatur Sipil Negara terutama Pegawai Negeri Sipil masih mempunyai stigma yang negatif, saat ini reformasi birokrasi yang digaungkan pemerintah masih belum dapat menghapus pandangan masyarakat yang menganggap aparatur negara lambat dalam menghadapi persoalan (Darmanto\& Fadillah, 2010).

Kinerja pegawai pemerintahan saat ini, masih dikelilingi oleh banyaknya praktek Korupsi, Kolusi dan Nepotisme serta berbagai stigma negatif lainnya. Hasil penilaian kinerja pegawai pada Badan Pengelolaan Pendapatan Daerah Kota Bandung selam lima tahun terakhir pada beberapa kategori mengalami penurunan. Permasalahan mengenai rendahnya tingkat disiplin pegawai dan masih buruknya pelayanan terhadap wajib pajak banyak disinyalir dapat memperburuk kinerja pegawai pada Badan Pengelolaan Pendapatan Daerah, indikasi lain yang berkaitan dengan rendahnya kinerja pegawai yaitu latar belakang pendidikan dan penempatan kerja dimana masih terdapat pegawai yang merasa kurang menikmati pekerjaannya karena tidak sesuai dengan bidang keahlian yang dimilikinya, hal ini berpengaruh terhadap tidak maksimalnya dalam bekerja (Elisabeth Siahaan, 2016). Masalah ini terjadi karena hampir semua pegawainya ditentukan oleh pusat dalam hal ini pemerintah Kota Bandung.

Apabila permasalahan tersebut tidak diatasi,makavisi misi serta tujuan organisasi tidak akan tercapai (Kiruja, 2013). Hasil penelitian yang dilakukan oleh Rudiansyah \& Nurdiaman (2016) menyimpulkan bahwa buruknya kinerja pegawai akan mempengaruhi kualitas pelayanan publik dan mempunyai implikasi yang luas dalam mencapai kesejahteraan masyarakat. Dampak lain dari persoalan buruknya kinerja pegawai pada organisasi pemerintahan dapat mengahambat terwujudnya sistem pemerintahan yang baik (good governance) (Astiasa, 2015).

Mengingat permasalahan mengenai rendahnya kinerja pegawai sangat penting dan mempunyai implikasi langsung terhadap kesejahteraan masyarakat secara luas, masalah kinerja pegawai dapat diatasi dengan pendekatan Sumber Daya Manusia (SDM) pada fungsi dasar Manajemen Learning and Development dengan meningkatkan kualitas Sumber Daya Manusia yang dimiliki melalui pengembangan sistem, standarisasi dan sertifikasi di berbagai profesi serta pengembangan, pengetahuan dan pelatihan berbasis kompetensi (Nassazi, 2013). Learning and Development SDM merupakan kegiatan yang harus dilaksanakan organisasi agar pengetahuan (knowledge), kemampuan (ability), dan keterampilan (skill) sesuai dengan pekerjaan sehingga dapat meningkatkan kinerja pegawai (Hassan, 2016). Faktor faktor yang dapat mempengaruhi kinerja pegawai yaitu learning, capacity, building, stress, working, environment, leadership, administrative practice, compensation, and motivation (Bajwa, 2016). Menurut Mangkunegara (2013) faktor faktor yang dapat mempengaruhi kinerja pegawai dapat bersumber dari dalam individu maupun dari luar individu. Faktor internal individu terdiri dari kemampaun potensi dan kemampuan reality (knowledge + sklill), sedangkan faktor ekternal adalah faktor yang mempengaruhi kinerja seseorang yang 
berasal dari lingkungan seperti sikap, tindakan rekan kerja, bawahan atau pimpinan, fasilitas kerja, dan iklim organisasi.

Berdasarkan faktor faktor yang mempengaruhi kinerja pegawai, disinyalir faktor knowledge (pengetahuan) memiliki peranan yang sangat penting untuk meningkatkan kinerja pegawai. Pengetahuan merupakan sumber daya organisasi penting untuk setiap perusahaan, terlepas dari lokasi, ukuran (kecil, menengah, maupun organisasi besar) dan jenisnya (publik atau swasta) (Omotayo, 2015). Pegawai yang menjalani pelatihan yang tepat cenderung mempertahankan pekerjaan mereka lebih lama daripada mereka yang tidak (Elnaga \& Imran, 2013). Melalui berbagai pelatihan dan berbagi pengetahuan diharapkan dapat meningkatkan kualitas Sumber Daya Manusia yang pada akhirnya dapat meningkatkan kinerja pegawai. Kriteria kinerja pegawai mencapai hasil yang lebih maksimal apabila didukung dengan knowledge yang dimiliki dan berkontribusi terhadap pencapaian dan pengembangan kinerja organisasi (Al-Hayaly \& Alnajjar, 2016).

Mengelola Pengetahuan untuk mencapai kinerja organisasi tidak hanya penting bagi sektor swasta, tapi memang begitu signifikan untuk sektor public (Mustapa \& Mahmood, 2016). Organisasi agar dapat berhasil dan bertahan hidup dalam ekonomi berbasis pengetahuan (k-economy), knowledge ini harus dikelola (managed), direncanakan dan diimplementasikan. Manajemen pengetahuan atau lebih dikenal dengan istilah knowledge management pada dasarnya dapat diimplementasikan sebagai strategi dengan sedikit atau tanpa tergantung dengan teknologi yang canggih seperti sekarang ini. Secara umum, knowledge management merupakan sebuah proses yang mengkoordinasikan penggunaan informasi, pengetahuan dan pengalaman (Al-Hayaly \& Alnajjar, 2016). Manajemen pengetahuan pada perkembangan saat ini, keberhasilannya banyak dipengaruhi berbagai sarana atau infrastruktur yang sesuai dengan kebutuhan organisasi, tuntutan lingkungan, dan dinamika teknologi.Pemerintah saat ini menyadari pentingnya $\mathrm{KM}$ dalam pembuatan kebijakan dan pelayanan kepada masyarakat . Hal ini terbukti dengan dikeluarkannya Peraturan MenpanRB Nomor 14 Tahun 2011 tentang Pedoman Pelaksanaan Program Manajemen Pengetahuan (Knowledge Management). Dalam peraturan tersebut, penerapan KM dimaksudkan untuk meningkatkan kemampuan organisasi dalam mengelola asset intelektualnya berupa pengetahuan dan pengalaman yang ada. Tujuannya adalah memanfaatkan aset tersebut untuk mencapai kinerja organisasi yang lebih baik untuk mempercepat pencapaian tujuan pelaksanaan reformasi birokrasi.

Hasil dari wawancara dengan kepala bidang perencanaan upaya Badan Pengelolaan Pendapatan Daerah Kota Bandung dalam memperbaiki kinerja pegawainya salah satunya adalah dengan mengimplementasikan Knowledge Management melalui berbagai program seperti pelatihan, pembentukan tim kerja, rotasi jabatan dan dengan terus mengembangkan system informasi dan tekhnologi.

Knowledge management telah diakui sebagai instrumen yang penting untuk mencapai tujuan khusus dari suatu organisasi dan bahkan suatu negara sehingga dapat mempertahankan pertumbuhan ekonomi serta keunggulan kompetitif (Ragab \& Arisha, 2013). Knowledge Management merupakan langkah untuk menangkap, mengorganisasikan, penyimpanan pengetahuan, dan pengalaman dari setiapindividu pekerja atau group pekerja didalam sebuah organisasi dan membuat knowledge tersedia untuk pekerja lainnya di dalam organisasi (Zwain, Teong, \& Othman, 2012). Fungsi KM terkait unsur people,processes, dan technology. Unsur people berkaitan dengan tacit knowledge merupakan pengetahuan individu yang diperoleh dari pengalaman keseharian dan sulit diduplikasikan atau diajarkan kepada orang lain, dalam hal ini dikategorikan ke dalam personal knowledge (Kosasih dan Budiani, 2007). Unsur proses terkait siklus KM yaitu menangkap, menciptakan, menyimpan dan menemukan kembali,serta memindahkan dan membagi pengetahuan (Agustyarini dkk, 2005), dikategorikan dalam bentuk job procedure dan learning organization.Sedangkan unsur technology merupakan sarana yang menghubungkan unsur People dan processes melalui media intranet/internet (Tsai dkk,2006)

Penerapan Knowledge Management (KM) oleh Badan Pengelolaan Pendapatan Daerah Kota Bandung diharapkan dapat meningkatkan kinerja pegawai, melalui KM diharapkan dapat merubah budaya kerja pada pada dinas tersebut lebih mengacu pada pada berbagi pengetahuan, sehingga pengetahuan semua karyawan dijadikan sebagai aset penting dalam perusahaan yang harus dikelola dengan baik.

Tujuan penelitian ini adalah untuk mengetahui gambaran knowledge management, kinerja pegawai dan seberapa besar pengaruh knowledge management terhadap kinerja pegawai.

\section{KAJIAN PUSTAKA}


Perkembangan dewasa ini mengajukan pada makin cepatnya perubahan dalam segala bidang kehidupan, akibatnya dari efek globalisasi serta pengembangan teknologi informasi yang sangat akseleratif. Kondisi ini jelas mengakibatkan perlunya cara-cara baru dalam menyikapi semua yang terjadi agar dapat tetap survive. Penekanan akan makin pentingnya kualitas sumber daya manusia (SDM) merupakan salah satu respon dalam menyikapi perubahan tersebut, dan ini tentu saja memerlukan upaya-upaya untuk meningkatkan dan mengembangkan SDM. Sehubungan dengan itu peranan ilmu pengetahuan menjadi makin menonjol, karena hanya dengan pengetahuanlah semua perubahan yang terjadi dapat disikapi dengan tepat. Ini berarti pendidikan memainkan peran penting dalam mempersiapkan SDM yang berkualitas dan kompetitif. Ketatnya kompetisi secara global khususnya dalam bidang ekonomi telah menjadikan organisasi usaha memikirkan kembali strategi pengelolaan usahanya dan SDM yang berkualitas dengan penguasaan pengetahuannya menjadi pilihan penting yang harus dilakukan dalam konteks tersebut.

Pertengahan tahun 1980 istilah knowledge management atau manajemen pengetahuan mulai popular dan sering menjadi topik pembicaraan di kalangan praktis maupun akademisi manajemen. Knowledge management berangkat dari ide dasar bahwa sumber daya yang paling berharga dari sebuah organisasi adalah pengetahuan yang dimiliki oleh SDM kinerja dan kesuksesan organisasi tergantung pada sejauh mana keefektifan SDM dalam menciptakan pengetahuan baru, berbagi pengetahuan dalam organisasi, dan menggunakan pengetahuan tersebut untuk memberikan yang terbaik untuk organisasi.

Konsep mengenai knowledge management telah menjadi salah satu konsep yang penting bagi manajemen dan menjadi bahan kajian ilmiah. Penerapannya di berbagai perusahaan profit maupun organisasi publik dapat memberikan kontribusi besar bagi pengembangan manajemen dalam rangka pencapaian tujuan organisasi secara efektif dan efisien.

Menurut Bhatt (2000) bahwa knowledge management memiliki elemen yang saling terkait satu sama lain, yaitu: people, process, dan technology. Tiga elemen knowledge management yaitu people, process, dan technology merupakan elemen penting yang dapat menentukan keberhasilan implementasi sistem knowledge management. Bahkan dikatakan bahwa knowledge management itu sendiri tak lain adalah integrasi dari people dan process, yang kemudian dimungkinkan dengan technology, untuk memfasilitasi pertukaran informasi, pengetahuan, dan keahlian sehingga meningkatkan performance organisasi. Unsur people berkaitan dengan tacit knowledge merupakan pengetahuan individu yang diperoleh dari pengalaman keseharian dan sulit diduplikasikan atau diajarkan kepada orang lain, dalam hal ini dikategorikan ke dalam personal knowledge (Kosasih dan Budiani, 2007). Unsur proses terkait siklus KM yaitu menangkap, menciptakan, menyimpan dan menemukan kembali, serta memindahkan dan membagi pengetahuan (Agustyarini dkk, 2005), dikategorikan dalam bentuk job procedure dan learning organization. Sedangkan unsur technology merupakan sarana yang menghubungkan unsur People dan proceses melalui media intranet/internet (Tsai dkk,2006)

Organisasi merupakan sekumpulan orang yang berada di dalamnya, baik organisasi yang berskala kecil maupun besar, orang atau manusia merupakan unsur penting dalam menentukan apakah sebuah organisasi dapat beroperasi dengan efektif dan efisien untuk mencapai tujuan organisasi tersebut (Mathis, R. L., Jackson, J. H., Valentine, S. R., \& Meglich, 2017). Pada dasarnya, gagal atau suksesnya sebuah organisasi dalam mencapai tujuannya sangat tergantung pada manusia yang mengelola organisasi tersebut. Manusia atau Karyawan yang berada dalam suatu perusahaan/organisasi biasanya disebut dengan Sumber Daya Manusia atau SDM.

Sebuah organisasi harus mengembangkan dan mengoptimalkan kapabilitas serta kinerjanya, diperlukan suatu manajemen untuk mengelolanya. Manajemen tersebut biasanya disebut dengan Manajemen Sumber Daya Manusia atau disingkat dengan MSDM. Manajemen sumber daya manusia adalah suatu prosedur yang berkelanjutan yang bertujuan untuk memasok suatu organisasi atau perusahaan dengan orang-orang yang tepat untuk ditempatkan pada posisi dan jabatan yang tepat pada saat organisasi memerlukannya (Stoner, 2006). Sumber daya manusia dianggap sebagai salah satu sumber terpenting perusahaan saat ini. Manajemen 
sumber daya manusia lebih penting daripada sumber daya saing lainnya karena orangorang ini menggunakan aset lain dalam organisasi, menciptakan daya saing dan mewujudkan tujuan. Oleh karena itu, organisasi harus memahami harapan tenaga kerja mereka untuk mencapai kinerja yang diinginkan. Realisasi harapan karyawan akan memungkinkan perilaku karyawan yang diinginkan dalam organisasi (Cania, 2014).

Teori serta konsep kinerja pegawai yang digunakan dalam penelitian ini mengadopsi konsep menurut menurut Bernadin dan Russel (Sutrisno, 2012:179-180) untuk mengetahui kinerja pegawai diperlukan kegiatan-kegiatan khusus yang digunakan untuk mengukur kinerja, yaitu Quality, merupakan tingkat sejauh mana proses atau hasil pelaksanaan kegiatan mendekati kesempurnaan atau mendekati tujuan yang diharapkan. Quantity merupakan jumlah yang dihasilkan, misalnya jumlah rupiah, unit dan siklus kegiatan yang dilakukan. Timeliness merupakan sejauh mana suatu kegiatan diselesaikan pada waktu yang dikehendaki, dengan memperhatikan koordinasi output lain serta waktu yang tersedia untuk kegiatan orang lain., Need for supervision merupakan tingkat sejauh mana seorang pekerja dapat melaksanakan suatu fungsi pekerjaan tanpa memerlukan pengawasan seorang supervisor untuk mencegah tindakan yang kurang diinginkan. Interpersonal impact merupakan tingkat sejauh mana karyawan memelihara harga diri, nama baik, dan kerjasama di antara rekan kerja dan bawahan.

Untuk menghasilkan kinerja yang baik, maka suatu organisasi membutuhkan sistem yang baik pula. Sistem ini bukan hanya peraturan atau baku yang ada melainkan juga melibatkan pihak-pihak yang terkait langsung yaitu sumberdaya manusianya. Salah satu sistem manajemen yang menawarkan suatu disiplin yang memerlakukan intelektual sebagai aset yang dikelola adalah knowledge management (Honeycutt, 2005). Melalui knowledge management akan teridentifikasi pengetahuan-pengetahuan yang dimiliki sebuah organisasi untuk meningkatkan kinerja dan menghasilkan berbagai inovasi.

Sejalan dengan penelitian yang dilakukan oleh Kosasih dan Budiani (2007) mengukur knowledge management pengaruhnya terhadap kinerja karyawan melibatkan 3 elemen yaitu personal knowledge, job procedure, dan technology. Pengalaman pernah/lama mengerjakan tugas tertentu akan memudahkan pegawai yang bersangkutan untuk melakukan tugas dan fungsinya sesuai dengan kewenangannya.
Karena dengan adanya pengalaman tersebut sudah terlatih untuk mengembangkan kecakapan untuk memecahkan masalah-masalah yang timbul, serta terlatih dalam mengemukakan ide dan pendapatnya. SOP atau prosedur pelaksanaan dasar dibuat untuk mempertahankan kualitas dan hasil kerja (Anshori, 2004).Dengan menggunakan SOP, maka tugas-tugas akan semakin mudah dikerjakan, juga customer akan terbiasa dengan sistem pelayanan yang ada. SOP dapat mengurangi waktu yang terbuang,dengan demikian diharapkan akan meningkatkan produktivitas kerja baik bagi manajemen atau pun bagi individu staf yang bersangkutan. Technology merupakan salah satu elemen pokok pada knowledge management, yang dikenal sebagai media yang mempermudah penyebaran explicit knowledge. Sarana komputer dalam hal ini sangat memengaruhi implementasi teknologi informasi pada perusahan.

Berdasarkan penjelasan mengenai pengaruh implementasi knowledge Management terhadap kinerja pegawai, maka disusun sebuah paradigma penelitian secara jelas digambarkan dalam Gambar 1.1 sebagai berikut:

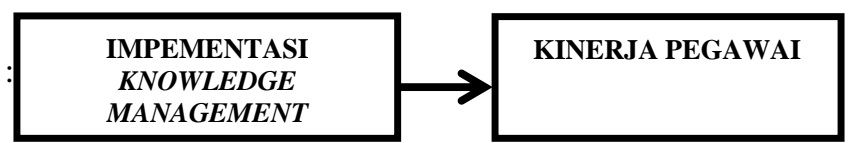

Gambar 1.1 Paradigma Pemikiran

\section{METODE PENELITIAN}

Metode penelitian menurut Sugiyono (2015:2) pada dasarnya merupakan cara ilmiah untuk mendapatkan data dengan tujuan dan kegunaan tertentu. Metode penelitian yang digunakan dalam penelitian ini adalah penelitian deskriptif dan verifikatif. Sekaran (2014:158) menjelaskan bahwa "Penelitian deskriptif dilakukan untuk mengetahui dan menjadi mampu untuk menjelaskan karakteristik variabel yang diteliti dalam suatu situasi".Penelitian deskriptif mencoba menggambarkan atau memahami karakteristik atau profil dari suatu variabel penelitian. Menurut Arifin (2011:41) menjelaskan bahwa penelitian desktriptif adalah penelitian yang digunakan untuk menggambarkan (to describe), menjelaskan, dan menjawab persoalan-persoalan tentang fenomena sebagaimana adanya maupun analisis hubungan antara berbagai variabel dalam suatu fenomena. Tujuan dari penelitian deskriptif adalah untuk menjelaskan secara sistematis, faktual, dan akurat mengenai fakta-fakta dan sifat-sifat populasi atau daerah tertentu. Maksud dari penggunaan metode penelitian deskriptif dalam penelitian ini adalah untuk mengetahui gambaran secara keseluruhan mengenai pengaruh implementasi knowledge management terhadap kinerja pegawai 
pada Badan Pengelolaan Pendapatan Daerah Kota Bandung.

Metode penelitian ini dilaksanakan melalui pengumpulan data dilapangan, maka metode yang digunakan dalam penelitian ini adalah metode survey explanatory.

Penelitian ini dilakukan untuk mengetahui gambaran pengaruh implementasi knowledge management terhadap kinerja pegawai. Variabel bebas Knowledge Management terdapat empat dimensi yaitu personal knowledge, learning organization, job procedure, dan technology. Pada penelitian ini variabel kinerja pegawai terdiri dari lima dimensi, dan dua puluh sembilan indikator, yaitu dimensi quality mengerjakan tugas sesuai yang diperintahkan, mengerjakan pekerjaan sesuai dengan standar yang telah ditetapkan, mengerjakan tugas tanpa kesalahan, cermat atas hasil kerja yang telah di capai, teliti dalam bekerja. Dimensi quantity dari indikator mengerjakan pekerjaan sesuai dengan target yang telah ditentukan, mengerjakan perkerjaan melebihi target yang telah ditentukan, tidak menunda nunda pekerjaan yang harus dikerjakan. Dimensi timeliness dari indikator tepat waktu dalam menyelesaikan pekerjaan, mengerjakan pekerjaan dengan akurat, melakukan pekerjaan lebih cepat dari waktu yang telah ditetapkan, menggunakan waktu yang tersisa untuk mengerjakan pekerjaan lainnya. Dimensi need for supervision dari indikator mampu melakukan fungsi pekerjaan tanpa memerlukan pengawasan atasan, melakukan pekerjaan dengan benar walaupun tanpa diawasi, tidak melanggar peraturan sekalipun tidak diawasi. Dimensi interpersonal impact dari indikator mampu bekerja sama dengan rekan kerja dan atasan, mampu menjaga nama baik perusahaan, mampu menjaga harga diri sebagai pegawai. Data primer primer dalam penelitian ini berupa data mentah dengan skala Likert untuk data tanggapan responden personal knowledge,learning organization, job procedure, dan technology terhadap kinerja pegawai. Adapun kriteria penilaian didasarkan pada pengukuran skala Likert. Menurut Sugiyono (2004) skor yang diberikan terhadap jawaban atas pertanyaan adalah sebagai berikut :

$\begin{array}{ll}\text { a. } & \text { Sangat setuju :7 } \\ \text { b. } & \text { Setuju : } 6 \\ \text { c. } & \text { Cukup setuju :5 } \\ \text { d. } & \text { Netral :4 } \\ \text { e. } & \text { Kurang setuju :3 } \\ \text { f. } & \text { Tidak setuju : } 2 \\ \text { g. } & \text { Sangat tidak setuju :1 }\end{array}$

Objek/unit analisis pada penelitian ini yaitu pegawai Badan Pengelolaan Pendapatan Daerah Kota
Bandung sebanyak 74 responden. Teknik smpling yang digunakan dalam penelitian ini adalah teknik probability yaitu Proportionate Stratified Random Sampling. Teknik ini digunakan bila populasi mempunyai anggota yang tidak homogen dan berstrata secara proporsional (Sugiyono, 2007:75). Stratified Random Sampling biasa digunakan pada populasi yang mempunyai susunan bertingkat atau berstata Margono (2010:126). Contohnya pada suatu perusahaan memiliki populasi dari berbagai bidang pekerjaan maka pembagian sampel harus adil dilakukan.

Berdasarkan penjelasan di atas, maka penentuan jumlah sampel yang diambil untuk memilih pegawai sebanyak 74 orang dari setiap departemen Penelitian ini dilakukan pada kurun waktu kurang dari satu tahun, sehingga teknik pengumpulan data yang digunakan pada penelitian ini adalah cross-sectional method. Teknik pengumpulan data yang digunakan adalah studi kepustakaan, studi lapangan dengan penyebaran kuesioner secara langsung ke perusahaan dan studi literatur. Dalam penelitian ini teknik pengumpulan data sebagai berikut:

1.Observasi (pengamatan), dilakukan dengan mengamati langsung objek yang berhubungan dengan masalah yang diteliti khususnya mengenai knowledge management dan kinerja pegawai

2.Studi kepustakaan, yaitu pengumpulan data dengan cara mempelajari buku, jurnal, situs web-site, majalah guna memperoleh informasi yang berhubungan dengan teori-teori dan konsep-konsep yang berkaitan dengan masalah dan variabel yang diteliti yaitu knowledge management dan kinerja pegawai

3.Wawancara, sebagai teknik komunikasi langsung dengan pihak Badan Pengelolaan Pendapatan Daerah Kota Bandung. Teknik wawancara yang digunakan yaitu teknik wawancara tidak terstruktur (Sugiyono, 2009:140) yaitu wawancara bebas dimana peneliti tidak menggunakan pedoman wawancara yang telah tersusun secara sistematis dan lengkap untuk pengumpulan datanya. Pedoman wawancara yang digunakan hanya berupa garis-garis besar permasalahan yang akan ditanyakan

4.Kuesioner, dilakukan dengan menyebarkan seperangkat daftar pertanyaan tertulis kepada responden yaitu pegawai Badan Pengelolaan Pendapatan Daerah Kota Bandung. Kuesioner ini mengemukakan beberapa pertanyaan yang mencerminkan pengukuran indikator dari variabel (X) yaitu knowledge management, variabel (Y) yaitu kinerja pegawai Badan Pengelolaan Pendapatan Daerah Kota Bandung. 


\section{HASIL PENELITIAN DAN PEMBAHASAN}

Menurut Bhatt (2000) bahwa KM memiliki elemen yang saling terkait satu sama lain, yaitu: People, process, dan technology. Tiga elemen KM yaitu people, process, dan technology merupakan elemen penting yang dapat menentukan keberhasilan implementasi sistem KM. Bahkan dikatakan bahwa KM itu sendiri tak lain adalah integrasi dari people dan process, yang kemudian dimungkinkan dengan technology, untuk memfasilitasi pertukaran informasi, pengetahuan, dan keahlian sehingga meningkatkan performansi organisasi.

People merupakan bentuk dasar untuk membentuk knowledge baru. Tanpa ada orang tidak akan ada knowledge (Collison dan Parcell, 2001). Personal knowledge atau pengetahuan yang diperoleh dari individu (perorangan) termasuk dalam kategori tacit knowledge. Process terdiri dari rangkaian aktivitas

menangkap,menyaring,mengesahkan,mentransformas ikan, dan menyebarkan pengetahuan ke seluruh perusahaan dilengkapi dengan menjalankan prosedur dan proses tertentu dalam implementasinya di terapkan melalui learning organization dan job procedure, sedangkan tekhnologi, merupakan aspek ketiga yang menjadi sebuah alat dalam mendukung unsur people maupun process berjalan dengan benar. Aspek technology merupakan sebuah enabler terjadi suatu pengelolaan pengetahuan, seperti sebagai alat untuk mengatur pengetahuan yang masuk, menyimpan pengetahuan yang dimasukkan kedalam suatu system knowledge management, dengan demikian dapat disimpulkan bahwa knowledge management mempunya empat dimensi yaitu personal knowledge, learning organization, job procedure dan technology

Variabel Knowledge Management terdapat empat dimensi yaitu personal knowledge, learning organization, job procedure, dan technology. Dimensi personal knowledge dengan sub experience terdiri dari enam indikator yaitu memiliki pengalaman pekerjaan di bidangnya, memiliki kepercayaan yang tinggi dalam melaksanakan pekerjaan, selalu menguasai pekerjaan yang diberikan, memiliki motivasi yang tinggi untuk menyelesaikan pekerjaan, membagi pengalaman yang dimiliki kepada rekan kerja, dan pengalaman dimiliki membatu proses pekerjaan.

Dimensi learning organization memiliki lima sub dimensi pertama personal mastery dengan indikator mampu menyelesaikan pekerjaan, selalu berbagi pengetahuan dengan rekan kerja, selalu memberi saran terhadap masalah pekerjaan, memiliki loyalitas yang tinggi terhadap pekerjaan, menciptakan hal baru untuk perusahaan, menerima pelatihan sesuai kebutuhan, pegawai mendapatkan peluang pelatihan. Sub dimensi ke dua Share Vision (berbagi visi) dengan indikator paham isi visi perusahaan, menjadikan visi perusahaan sebagai pedoman dalam melaksanakan pekerjaan, dan merasa bertanggung jawab terhadap pencapai tujuan perusahaan. Sub dimensi ke tiga yaitu Mental Model (Model Mental) dengan indikator menghargai adanya perbedaan pendapat, bersedia menerima kritik dari siapapun, kebebasan mengemukan pendapat di dalam perusahaan, bersikap ramah terhadap rekan kerja, Sopan dalam bertidak, bersikap sopan dalam bertutur kata. Sub dimensi yang ke empat yaitu System thinking (berpikir system) dengan indikator pentingnya kerjasama dalam menyelesaikan pekerjaan, dengan sukarela membantu pekerjaan rekan kerja yang belum selesai, memiliki kepedulian terhadap masalah perusahaan, keberhasilan satu unit kerja mempengaruhi unit kerja lain. Sub dimensi ke lima yaitu team learning (pembelajaran tim) dengan indikator terbinanya hubungan erat antar pegawai tanpa memandang status jabatan, memberi ide/gagasan dalam kelompok unit kerja, terbuka terhadap masalah yang terjadi, mampu bekerja sama denga team, memberikan pendapat ketika rapat.

Dimensi Job Procedure (Prosedur Kerja) dengan sub dimensi Standar Operational Procedure (SOP) memiliki indikator paham mengenai prosedur dalam melaksanakan tugas, Menjadikan SOP sebagai pedoman dalam melaksanakan pelayanan, SOP dapat meningkatkan kemampuan kerja, SOP dijadikan sebagai acuan dalam melaksanakan pelatihan bekerja.

Dimensi technology dengan sub dimensi penggunaan internet/intranet memiliki indikator internet dapat menjadi sarana untuk mendapat dan menyebarkan informasi, memiliki keterampilan dalam menggunakan internet, Fasilitas internet yang ada dapat membantu proses kerja pegawai, Fasilitas internet membantu dalam menyimpan data.

Berdasarkan hasil pengolahan data yang dilakukan melalui penyebaran angket dengan melibatkan 74 responden pada pegawai Badan Pengelolaan Pendapatan Daerah Kota Bandung dapat diukur melalui perhitungan rata-rata dimensi dan perhitungan skor keseluruhan. Berikut ini dipaparkan hasil dari rekapitulasi perhitungan skor sebagai berikut:
TABEL 1.1
REKAPITULASI DIMENSI KNOWLEDGE MANAGEMENT 


\begin{tabular}{clccc}
\hline No. & \multicolumn{1}{c}{ Dimensi } & $\begin{array}{c}\text { Total } \\
\text { Skor }\end{array}$ & $\begin{array}{c}\text { Skor } \\
\text { Ideal }\end{array}$ & $\%$ \\
\hline 1. & $\begin{array}{l}\text { Personal } \\
\text { Knowledge }\end{array}$ & 2132 & 2590 & $82 \%$ \\
2. & $\begin{array}{l}\text { Learning } \\
\text { Organization }\end{array}$ & 10210 & 12432 & $82 \%$ \\
3. & Job Procedure & 1680 & 2072 & $81 \%$ \\
4. & Tekhnologi & 1692 & 2072 & $81 \%$ \\
\hline & $\quad$ Total & 15714 & 19166 & 81,9 \\
\hline & Berdasarkan & Tabel & 11 &
\end{tabular}

management skor paling tinggi yaitu terdapat pada dimensi personal knowledge dan learning organization dengan persentase sebesar $82 \%$, sementara dimensi paling rendah yaitu pada dimensi job procedure dan tekhnologi memperoleh skor $81 \%$.

Mengelola Pengetahuan untuk mencapai kinerja maksimal tidak hanya penting bagi sektor swasta, tapi memang begitu signifikan untuk sektor public (Mustapa \& Mahmood, 2016).), knowledge ini harus dikelola (managed), direncanakan dan diimplementasikan. Knowledge management pada dasarnya dapat diimplementasikan sebagai strategi dengan sedikit atau tanpa tergantung dengan teknologi yang canggih seperti sekarang ini. Secara umum, knowledge management merupakan sebuah proses yang mengkoordinasikan penggunaan informasi, pengetahuan dan pengalaman (Al-Hayaly \& Alnajjar, 2016). Manajemen pengetahuan pada perkembangan saat ini, keberhasilannya banyak dipengaruhi berbagai sarana atau infrastruktur yang sesuai dengan kebutuhan organisasi, tuntutan lingkungan, dan dinamika teknologi. Skor tertinggi skor hasil jawaban responden yaitu terdapat pada dimensi personal knowledge dengan memperoleh skor 2132 (82 \%), dan learning organization dengan perolehan skor 10210 (82\%), masuk dalam kategori baik. Berdasarkan hasil ini diketahui bahwa pegawai BPPD Kota Bandung adalah mereka yang mempunyai pengalaman kerja. Dalam teori yang dipaparkan pada bab sebelumnya, pengalaman adalah salah bentuk tacit knowledge yang secara sederhana berarti pengetahuan yang tidak terlihat dan berada dalam diri seseorang.

Dengan pengalaman yang dimiliki responden setuju bahwa pekerjaan yang mereka lakukan akan lebih mudah. Seperti yang kita ketahui bahwa responden pada penelitian ini berasal dari berbagai bidang yaitu perencanaan, bidang pajak dan pendaftaran, bidang pajak penetapan dan bidang pengendalian. Dalam penelitian ini terungkap berdasarkan item pertanyaan yang diberikan kepada para responden pekerjaan yang dilakukan oleh setiap karyawan memberikan mereka pengalaman dan pengetahuan baru bagi mereka sehingga semakin sering mereka melakukan pekerjaan tersebut maka semakin baik pengalaman dan pengetahuan yang dimiliki karyawan. Penelitian terdahulu yang dilakukan (Kosasih dan Budiani, 2007) juga sejalan dengan hasil penelitian ini dimana indikator personal knowledge atau pengetahuan pribadi salah satunya pengalaman akan sangat berpengaruh terhadap kinerja pegawai. Pegawai yang memiliki pengalaman di bidang pekerjaannya terbukti memiliki rasa percaya diri dan motivasi yang tinggi untuk menyelesaikan pekerjaan.Melalui hasil dari penelitian ini terungkap bahwa rata rata pegawai BPPD kota Bandung memiliki pengalaman di bidang pekerjaan. Pengalaman yang diperoleh masing masing pegawai pada tiap bagian atau divisi tentunya berbeda-beda berdasarkan situasi dan kondisi yang tidak dapat diprediksi. Definisi experience yang diambil dari kamus bahasa Inggris adalah the process of gaining knowledge or skill over aperiod of time through seeing and doing things rather than through studying. Yang artinya proses memperoleh pengetahuan atau kemampuan selama periode tertentu dengan melihat dan melakukan hal-hal dari pada dengan belajar. Semakin karyawan memiliki personal knowledge yang tinggi, maka akan menghasilkan kinerja yang lebih baik. Hasil penelitian ini pun mengambarkan bahwa pada mengambarkan bahwa pegawai BPPD menjadikan organisasi sebagai media pembelajaran atau learning organization untuk terus meningkatkan kapasitas dan kemampuan diri melaui berbagai kegiatan pelatihan dan pengembangan Sumber daya Manusia. Menurut Senge (1994), learning organization atau organisasi pembelajar adalah organisasi yang anggota organisasinya (orangorangnya) secara terus menerus meningkatkan pengetahuannya kapasitasnya untuk menghasilkan sesuatu yang menjadi hasratnya, organisasi yang menumbuh kembangkan pola berpikir penciptaan sesuatu yang baru, organisasi yang memberikan kebebasan untuk menyampaikan aspirasinya, dan organisasi yang anggotanya secara terus menerus belajar.

Sementara skor terendah pada dimensi job procedure dan tekhnologi masing -masing memperoleh skor 1680 dan 1692 dengan persentase sebesar $81 \%$ hanya terpaut satu persen mengambarkan bahwa penerapan SOP dan penerapan tekhnology pada BPPD kota Bandung termasuk dalam kategori baik. SOP atau prosedur pelaksanaan dasar dibuat untuk mempertahankan kualitas dan hasil kerja (Anshori, 2004). Dengan menggunakan SOP, maka tugas-tugas akan semakin mudah dikerjakan, juga customer akan terbiasa dengan sistem pelayanan yang ada. SOP dapat mengurangi 
waktu yang terbuang, dengan demikian diharapkan akan meningkatkan produktivitas kerja baik bagi manajemen atau pun bagi individu staf yang bersangkutan, sedangkan penggunaan tekhnologi terutama fasilitas internet dari hasil penelitian pada BPPD kota hampir semua pegawai dapat mengoperasikan fasilitas internet dengan baik hal ini tentunya sangat membatu proses pelayanan terhadap masyarakat dalam rangka peningkatan pajak daerah. Teknologi internet salah satu elemen pokok yang terdapat pada knowledge management, dikenal sebagai media yang mempermudah penyebaran explicit knowledge. Teknologi internet membantu organisasi untuk proses penyebaran pengetahuan dimana hal ini didasarkan pada kebutuhan untuk mengakses pengetahuan dan melakukan kolaborasi, komunikasi serta sharing knowledge secara "online

Skor minimum garis kontinum knowledge management yaitu 2738 dan skor maksimum garis knowledge management yaitu 19166. Kategori sangat tidak baik terletak pada interval 2738 sampai 5084,8, kategori tidak baik terletak pada interval 5084,8 sampai 7431,6, kategori cukup tidak baik terletak pada interval 7431,6 sampai 9778,4, kategori sedang terletak pada interval 9778,4 sampai 12125,2, kategori cukup baik terletak pada interval 12125,2 sampai 14472, kategori baik terletak pada interval 14472 sampai 16818 dan kategori sangat baik terletak pada interval 16818 sampai 19166.

Secara keseluruhan variabel knowledge management memperoleh skor 15714, apabila di persentasekan kedalam skor ideal maka diperoleh persentase sebesar $81,9 \%$ masuk dalam kategori baik. Penelitian yang dilakukan oleh Choirina (2014) menyatakan bahwa knowledge management yang didukung oleh teknologi informasi berpengaruh signifikan terhadap kinerja pegawai. Hasil penelitian Rasula, Vuksic, \& Sremberger (2012), Gholami, Asli, Nazari-Shirkouhi, \& Noruzy (2013), dan Al-Hayaly \& Alnajjar (2016) menyatakan bahwa knowledge management berpengaruh terhadap peningkatan kinerja pegawai.

Skor tersebut secara kontinum dapat digambarkan sebagai berikut:

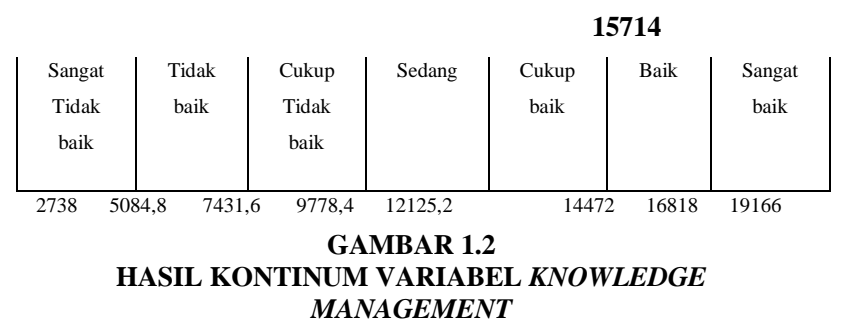

\section{Gambaran Kinerja Pegawai}

Sebuah organisasi yang modern baik organisasi publik maupun non publik, penilaian kinerja memberikan kontribusi penting bagi perusahaan untuk digunakan dalam menjelaskan tujuan dan standar-standar kinerja dan memotivasi individu di waktu yang akan datang. Sudut pandang kinerja baik tentang berbagai hal seperti kemampuan, keletihan, kekurangan dan potensinya. Sondang Siagian (2008:223-224) menjelaskan bahwa bagi individu penilaian kinerja berperan sebagai umpan pada gilirannya bermanfaat untuk menentukan tujuan, jalur, rencana dan pengembangan karirnya. Sedangkan bagi organisasi, hasil penilaian kinerja sangat penting dalam kaitannya dengan pengambilan keputusan tentang berbagai hal seperti identifikasi kebutuhan program pendidikan dan pelatihan, rekrutmen, seleksi, program pengenalan, penempatan, promosi, sistem balas jasa, serta berbagai aspek lain dalam proses manajemen SDM.

Kinerja atau performance merupakan gambaran mengenai tingkat pencapaian pelaksanaan suatu program kegiatan atau kebijakan dalam mewujudkan sasaran, tujuan, visi dan misi organisasi yang dituangkan melalui perencanaan strategis suatu organisasi (Moeheriono, 2014:95). Kinerja karyawan merupakan hal yang sangat penting dalam usaha perusahaan untuk mencapai tujuannya serta menjadi salah satu faktor utama keberhasilan suatu perusahaan. Pencapaian kinerja dapat diukur dengan standar akurasi, kelengkapan, biaya, dan kecepatan yang telah ditentukan sebelumnya. Kinerja karyawan dapat diwujudkan dalam peningkatan produksi, kemudahan dalam menggunakan teknologi yang baru, pekerja yang memiliki motivasi yang tinggi (Hafeez \& Akbar, 2015:53).Bernadin dan Russel (1993) mengemukakan terdapat lima dimensi dari kinerja yaitu quality,quantity, timelines, need for supervision, dan personal impact.

Berdasarkan hasil pengolahan data yang dilakukan melalui penyebaran angket terhadap 74 responden pada pegawai Badan Pengelolaan Pendapatan Daerah kota Bandung kinerja pegawai dapat diukur melalui perhitungan rata-rata dimensi dan perhitungan skor keseluruhan. Berikut ini dipaparkan hasil dari rekapitulasi perhitungan skor:

TABEL 1.2

REKAPITULASI DIMENSI KINERJA PEGAWAI 


\begin{tabular}{lllll}
\hline No. & Dimensi & $\begin{array}{c}\text { Total } \\
\text { Skor }\end{array}$ & $\begin{array}{c}\text { Skor } \\
\text { Ideal }\end{array}$ & $\mathbf{\%}$ \\
\hline Kinerja Karyawan & & & \\
\hline 1. & Quality & $\mathbf{2 2 2 6}$ & $\mathbf{2 5 9 0}$ & $\mathbf{8 6 \%}$ \\
2. & Quantity & $\mathbf{1 3 1 8}$ & $\mathbf{1 5 5 4}$ & $\mathbf{8 5 \%}$ \\
3. $\quad$ Need for Supervision & $\mathbf{1 7 7 7}$ & $\mathbf{2 0 7 2}$ & $\mathbf{8 6 \%}$ \\
4. $\quad$ Timeliness & $\mathbf{1 7 8 3}$ & $\mathbf{2 0 7 2}$ & $\mathbf{8 6 \%}$ \\
5. $\quad$ Interpersonal impact & $\mathbf{1 3 5 5}$ & $\mathbf{1 5 5 4}$ & $\mathbf{8 7 \%}$ \\
\hline \multicolumn{2}{l}{ Total } & $\mathbf{8 4 5 9}$ & $\mathbf{9 8 4 2}$ & $\mathbf{8 6 \%}$ \\
\hline
\end{tabular}

Berdasarkan hasil penelitian kinerja BPPD

Kota Bandung melalui penyebaran angket terhadap 74 responden pada dimensi quality memperoleh skor 1318 atau 85 persen artinya sebagian besar pegawai beranggapan telah melakukan pekerjakan sesuai dengan yang diperintahkan atau ssuai dengan SOP yang telah ditetapkan, namun masih ada pegawai yang merasa kinerja yang mereka hasilkan kurang memuaskan karena beberapa faktor salah satunya kurangnya skill dan pemahaman terhadap SOP pada dimensi quantity perolehan skor menncapi 1318 atau 85 persen atau sebagai besar responden beranggapan bahawa mereka telah mengerjakan pekerjakan sesuai dengan target yang telah ditentukan atau ada sebagian kecil yang beranggapan merasa belum mencapai target yang ditentukan hal ini bisa disebakan karena kurang skill ataupun karena faktor lain seperti pengalaman dan disiplin kerja. Hasil penelitian mengenai dimensi Need for Supervision perolehan skor 1777 atau 86 persen hal ini menggambarkan sebagai besar pegawai BPPD dapat melakukan pekerjakan sesuai dengan SOP nya meskipun tanpa diawasi pimpinan atau pengawas, namun dalam hal ini penelitian masih menemukan pegawai yang kinerja harus diawasi. Pengawasan merupakan hal yang penting agar suatu upaya yang telah direncanakan sebelumnya dapat diwujudkan serta untuk mengetahui kelemahan-kelemahan, sehingga berdasarkan pengamatan pengamatan tersebut dapat diambil suatu tindakan untuk memperbaikinya (Dugguh \& Dennis, 2014)

Skor tertinggi yaitu terdapat pada dimensi interpersonal impact memperoleh skor sebanyak 1355 atau $87 \%$, sementara dimensi paling rendah yaitu pada quantity memperoleh skor 1318 atau $85 \%$. Secara keseluruhan variabel kinerja karyawan memperoleh skor 8459, apabila di peresentasekan kedalam skor ideal maka diperoleh persentase sebesar $86 \%$, dapat dikatakan bahwa hampir seluruh responden menyatakan kinerja kerja pada BPPD Kota Bandung dalam kategori tinggi. Skor ideal kinerja pegawai adalah 15022 untuk 29 item pernyataan. Berdasarkan nilai kontinum variabel kinerja karyawan yaitu 8459 sesuai dengan data penelitian yaitu termasuk kedalam kategori tinggi, dengan demikian dapat dikatakan bahwa pegawai merasakan kinerja yang baik di BPPD, akan tetapi kinerja pegawai tersebut masih perlu ditingkatkan karena semua dimensi berada di bawah skor ideal.

Wibowo (2011:229) menjelaskan bahwa pengukuran terhadap kinerja perlu dilakukan untuk mengetahui apakah selama pelaksanaan kinerja terdapat deviasi dari rencana yang telah ditentukan, atau apakah kinerja dapat dilakukan sesuai jadwal waku yang ditentukan, atau apakah hasil kinerja telah tercapai sesuai dengan yang diharapkan. Untuk melakukan penilaian tersebut diperlukan kemampuan untuk mengukur kinerja sehingga diperlukan adanya ukuran kinerja. Penilaian kinerja adalah menilai kerja seseorang dengan membandingkan hasil kerja yang sudah dicapai dengan standar kerja, rencana, tujuan, jadwal waktu yang sudah ditentukan. Kinerja pegawai yang baik adalah salah satu faktor yang sangat penting dalam upaya prganisasi untuk meningkatkan produktivitas. Kinerja merupakan indikator dalam menentukan bagaimana usaha untuk mencapai tingkat produktivitas yang tinggi dalam suatu organisasi atau perusahaan.

Skor ideal kinerja pegawai adalah 11200 untuk 19 item pernyataan. Perolehan skor berdasarkan hasil pengolahan dari variabel kinerja karyawan adalah 8459 atau $86 \%$, skor tersebut secara kontinum dapat digambarkan sebagai berikut

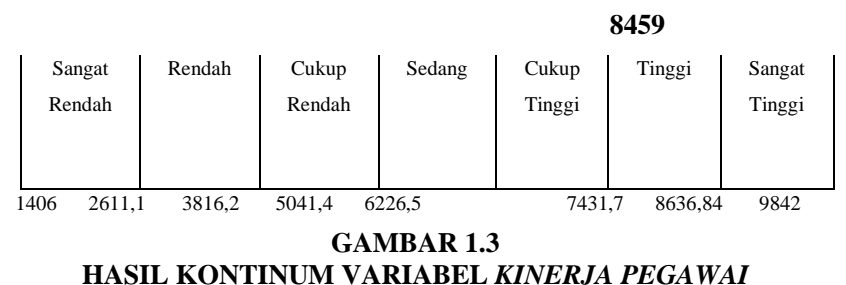

Berdasarkan pada nilai kontinum variabel kinerja karyawan yaitu 8459 sesuai dengan data penelitian yaitu termasuk kedalam kategori tinggi, dengan demikian dapat dikatakan bahwa pegawai merasakan kinerja yang baik di BPPD, akan tetapi kinerja pegawai tersebut masih perlu ditingkatkan karena semua dimensi berada di bawah skor ideal.

\section{KESIMPULAN DAN REKOMENDASI Kesimpulan}

Berdasarkan pembahasan teori, hasil penelitian, dan pengujian analisis regresi linear 
sederhana yang dilakukan mengenai pengaruh implementasi knowledge management terhadap kinerja Badan Pengelolaan Pendapatan Daerah Kota bandung dapat disimpulkan sebagai berikut:

1. Gambaran mengenai implementasi knowledge management pada Badan Pengelolaan Pendapatan Daerah Kota Bandung berada pada kategori baik. Hal ini dapat dilihat dari dimensi yang tertinggi hingga terendah variabel knowledge management perolehan skor tertinggi skor yaitu terdapat pada dimensi personal knowledge dan learning organization..Skor terendah terdapat pada dimensi job procedure dan tekhnologi Hal ini menunjukan bahwa sebagian besar pegawai BPPD merupakan pegawai yang telah mempunyai pengalaman dan menjadi organiasi sebagai media pembelajaran untuk terus meningkatkan kapsitas dan kemampuan diri

2. Gambaran Kinerja pada Badan Pengelolaan Pendapatan Dearah Kota Bandung menurut penelitian ini berada pada kategori tinggi. Skor tertinggi yaitu terdapat pada dimensi interpersonal impact sementara dimensi paling rendah yaitu pada quantity. Secara keseluruhan, dengan demikian dapat dikatakan bahwa pegawai merasakan kinerja yang baik di BPPD.

3. Berdasarkan penelitian ini menyatakan bahwa implementasi knowledge management berpengaruh positif terhadap kinerja pegawai. Hal ini menunjukan bahwa semakin baik implementasi knowledge management makan semakin tinggi kinerja pegawai.

\subsection{Saran}

Berdasarkan hasil penelitian, maka rekomendasi mengenai implementasi knowledge management dan kinerja pegawai yaitu sebagai berikut :

1. Dalam penerapan knowledge management BPPD perlu lebih meningkatkan job procedure dan technology melalui peningkatan pemahaman pengenai SOP kepada pegawainya, serta meningkatkan fasilitas internet infrastruktur, system, maupun peningkatan keterampilan penggunaan fasilitas internet bagi pegawainya agar dapat membantu pekerjaan menjadi lebih efektif dan efisien. sehingga pelayanan terhadap wajib pajak bisa lebih dimaksimalkan
2. Untuk meningkatkan kinerja pegawai BPPD quantity pekerjaan lebih ditingkatkan, para pegawai hendaknya saling bekerjasama dan yang memiliki pengalaman dan pengetahuan lebih bisa menyempatkan pegawai yang lain yang tidak mampu menyelesaikan pekerjaannya sesuai dengan target.

3. Supaya Kinerja pegawai terus meningkat maka penerapan implementasi knowledge management terus ditingkatkan. Penerapan knowledge management dalam meningkatkan kinerja pegawa akan berhasil apabila terbina sinergitas antar pegawai, kerja sama tim, penempatan pegawai yang berpengalaman. Bagi BPPD diharapkan memberikan perhatian lebih terhadap pengetahuan yang dimiliki pegawainya melalui pelaksanaan pelatihan dan pengembangan Sumber Daya Manusia

4. Bagi peneliti selanjutnya diharapkan dapat menjadikan kekurangan dalam penelitian ini sebagai bahan untuk melakukan penelitian selanjutnya.

\section{DAFTAR PUSTAKA}

Abdul Kadir, T. C. T. (2006). Pengenalan Teknologi Informasi dan Komunikasi. Yogyakarta: Penerbit Andi.

Abdullah, M. (2014). Manajemen dan Evaluasi Kinerja Karyawan. Yogyakarta: Aswaja Pressindo.

Al-Hayaly, M. A. M. S., \& Alnajjar, F. J. S. (2016). Knowledge Management Processes and Their Impact on Organizational Performance, the Adoption Balanced Scorecard: The Moderating Role of Quality Assurance Standards-An Applied Study on Private Jordanian Universities. International Journal of Business and Management, 11(6), 70. https://doi.org/10.5539/ijbm.v11n6p70

Ardana, Komang, Mujiati, Ni Wayan, Mudiartha Utama, I. W. (2012). Manajemen Sumber Daya Manusia. Yogyakarta: Graha Ilmu.

Arifin, Z. (2011). Penelitian Pendidikan: Metode dan Paradigma Baru. Bandung: PT. Remaja Rosdakarya.

Arikunto, S. (2010). Prosedur Penelitian Suatu Pendekatan Praktek. Jakarta: Rineka Cipta.

Astiasa, E. F. (2015). Kebijakan Hukum Pengembangan Kualitas Sumber Daya Manusia 
Journal of Business Management Education | Volume 3, Number 3, December 2018, page. 123-135

Dalam Peningkatan Kinerja AparaturSipil Negara Di Kota Kediri.

Ayu, I., \& Nugrahini, P. (2016). Penilaian kinerja berdasarkan, 4, 829-856.

Bajwa, J. K. (2016). Factors Affecting Employee Job Performance: With Special Reference To Banking Sector, (April), 114-117.

Bangun, W. (2012). Manajemen Sumber Daya Manusia. Bandung: Erlangga.

Cania, L. (2014). The Impact of Strategic Human Resource Management on Organizational Performance. Journal of Naval Science and Engineering, 6(2), 100-116.

Charis Christiani. (2013). Pengaruh Kinerja Aparat Terhadap Tingkat Kepuasan Masyarakat Di Kecamatan Gemuh Kabupaten Kendal, (6).

Choirina, F. D. (2014). Analisis Pengaruh Praktek Knowledge Management Dalam Memediasi Dukungan Information Technology Terhadap Kinerja Karyawan.

Copetrol, E. S. a. (2015). K Nowledge M Anagement At, 6(1), 1-8.

Darmanto, \& Fadillah, S. (2010). Kinerja Aparatur Pemerintah Daerah dalam Rangka Pelayanan Publik. Ilmu Administrasi Negara, 10(2), 192 203. Retrieved from http://ejournal.unri.ac.id/index.php/JIANA/artic le/download/1069/1062

Davis, W. B. W. dan K. (2003). Human Resources and Personnel Management (4th ed.). Singapore: Mc Graw Hill.

DeCenzo, D. A., Robbins, S. P., \& Verhulst, S. L. (2015). Fundamentals of Human Resource

\& Sons, Inc

Management (12th Editi). USA: John Wiley

Elisabeth Siahaan, P. G. A. L. (2016). Improvemet of Employee Banking Performance Based on Competency Improvement and Placement Working Through Creer Development. International Business Management, 10 (3), 255-261.

Elnaga, A., \& Imran, A. (2013). The Effect of Training on Employee Performance. European Journal of Business and Management, 5(4), 137-147. https://doi.org/10.2991/gecss-14.2014.90

Gholami, M., Asli, M., Nazari-Shirkouhi, S., \& Noruzy, a. (2013). Investigating the influence of knowledge management practices on organizational performance: An empirical study. Acta Polytechnica Hungarica, 10(2), 205-216.

Hafeez, U., \& Akbar, W. (2015). "Impact of Training on Employees Performance" (Evidence from Pharmaceutical Companies in Karachi, Pakistan). Business Management and Strategy, 6(1), 49. https://doi.org/10.5296/bms.v6i1.7804

Hasan, I. (2010). Pokok-pokok Materi Statistik 2: Statistik Inferensif. Penerbit Bumi Aksara.

Hassan, S. (2016). Impact of HRM Practices on Employee ' s Performance, 6(1), 15-22. https://doi.org/10.6007/IJARAFMS/v6-i1/1951

Iqbal, A., Ijaz, M., Latif, F., \& Mushtaq, H. (2015). Factors Affecting the Employee'S Performance: a Case Study of Banking Sector in Pakistan. European Journal of Business and Social Sciences, 4(08), 309-318. Retrieved from http://www.ejbss.com/recent.aspx-/

Khan, A. A., Abbasi, S. O. B. H., Waseem, R. M., Ayaz, M., \& Ijaz, M. (2016). Impact of Training and Development of Employees on Employee Performance through Job Satisfaction: A Study of Telecom Sector of Pakistan. Business Management and Strategy, 7(1), 29-46. https://doi.org/10.5296/bms.v7i1.9024

Kiruja, E. (2013). Effect of Motivation on Employee Performance In Public Middle Level Technical Training Institutions In Kenya. Managementjournal.Info, 2(4), 73-82. Retrieved from http://www.managementjournal.info/abstract.p hp? $\mathrm{id}=383$

Kosasih, N., \& Budiani, S. (2007). Pengaruh Knowledge Management Terhadap Kinerja Karyawan : Studi Kasus Departemen, 80-88.

Mahsun, M. (2006). Pengukuran Kinerja Sektor Publik. Yogyakarta: BPFE - UGM.

Malholtra, Y. (2005). Integrating knowledge management technologies i $\mathrm{n}$ organizational business processes: getting real time enterprises to deliver real business performance",. Journal of Knowledge Management, Vol. 9 Iss.

Mangkunegara, A. P. (2013). Manajemen Sumber Daya Manusia Perusahaan. Bandung: Remaja Rosdakarya.

Masharyono. (2015). Pengaruh Job Characteristics terhadap Semangat Kerja Pegawai (Survey pada Pegawai PNS di Lingkungan Disparbud 
Jabar), 3(3), 813-830.

Masharyono, S. H. S. (2015). Analisis Job Performance Pegawai Honorer Administrasi Dengan Kompetensi Dan Job Characteristics Dalam Mendukung Universitas Pendidikan Indonesia, 120-137.

Mathis, R. L., Jackson, J. H., Valentine, S. R., \& Meglich, P. A. (2017). Human Resource Management (Fifteenth). USA: Cengage Learning.

McInerney, C. (2002). Knowledge Management and the Dynamic Nature of Knowledge" Journal of The American Society for Information Sci ence and Technology., 53 (12), 1.

Moeheriono. (2014). Pengukuran Kinerja Berbasis Kompetensi, Edisi Revisi. Jakarta: Rajawali Pers.

Mustapa, A. N., \& Mahmood, R. (2016). Knowledge management and job performance in the public sector: The moderating role of public organizational commitment. International Journal of Research in Business Studies and Management, 3(7), 28-36.

Nasehudin, Toto Syatori, N. G. (2012). Metode penelitian kuantitatif. Bandung: Pustaka Setia.

Nasehudin, Toto Syatori, N. G. (2012). Metode penelitian kuantitatif. Bandung: Pustaka Setia.

Nassazi, A. (2013). Effects Of Training On Employee Performance . Evidence From Uganda. Business Economics and Tourism, 57. Retrieved from http://theseus32kk.lib.helsinki.fi/bitstream/handle/10024/67401 /THESIS.pdf?sequence $=1$

Nawawi, I. (2012). Manajemen Pengetahuan (Knowledge Management). Bogor: Ghalia Indonesia.

Nazir, M. (2005). Metode Penelitian. Jakarta: Ghalia Indonesia.

Nonaka. (2007). Knowledge emergence: Social, technical, and evolutionary dimensions of knowledge creation. New York: Oxford University Press.

Omotayo, F. O. (2015). Knowledge Management as an important tool in organisational management: A review of literature. Library Philosophy and Practice (e-Journal)., 1238, 123. Retrieved from http://digitalcommons.unl.edu/libphilprac/1238

Osunde, C. (2015). Privatization of Public Enterprises in Nigeria: Impact on employees' performance and managerial implications. International Journal of Research Granthaalayah, 3(1989), $32-38$.

Ragab, M. A. F., \& Arisha, A. (2013). Knowledge management and measurement: a critical review. Journal of Knowledge Management, 17(6), 873-901. https://doi.org/10.1108/JKM12-2012-0381

Rasula, J., Vuksic, V. B., \& Sremberger, M. I. (2012). The Impact of Knowledge Management on Organizational Performance. Economic and Business Review, 14(2), 147-168. https://doi.org/10.5539/ass.v11n23p153

Rudiansyah, U., \& Nurdiaman, M. (2016). Pengaruh Kinerja Pegawai Terhadap Peningkatan Pelayanan Di Perusahaan Daerah Air Minum ( PDAM ), 1-10.

S. Schuler, R. dan S. E. J. (2012). Manajemen Sumber Daya Manusia, (Menghadapi Abad Ke21). Jakarta: PT. Gelora Aksara Pratama.

Sedarmayanti. (2013). Manajemen Sumber Daya Manusia. Bandung: Refika Aditama.

Sekaran, U. (2014). Research Methods For Business. Jakarta: Salemba Empat.

Senen, S. H. (2016). Kontrak Rumah Sakit Umum Subang, 1(2), 81-90.

Senen, S. H. (2016). Pengaruh gaya kepemimpinan dan budaya organisasi terhadap kinerja karyawan pt sugih instrumendo abadi di padalarang, 1(2), 59-69.

Senen, S. H. (2016). Pengaruh Lingkungan Dan Kemampuan Kerja Terhadap Kinerja Karyawan $\mathrm{Pt}$. Ronadamar Sejahtera Cabang Bandung, 1(2), 47-55. 